\title{
PERAN DESAIN TATA RUANG MUSHOLA AL-HIDAYAH RT.06 RW.05 KELURAHAN PENANGGUNGAN KOTA MALANG TERHADAP PEMENUHAN FUNGSI EKO-DESAIN
}

\author{
Sri Winarni \\ Dosen Prodi Arsitektur, Fak. Teknik Sipil dan Perencanaan, ITN Malang \\ e-mail: sriwinarni@lecturer.itn.ac.id \\ Putri Herlia Pramitasari \\ Dosen Prodi Arsitektur, Fak. Teknik Sipil dan Perencanaan, ITN Malang \\ e-mail: putri_herlia@lecturer.itn.ac.id \\ Maria Istiqoma \\ Dosen Prodi Arsitektur, Fak. Teknik Sipil dan Perencanaan, ITN Malang \\ e-mail: mariaistiqoma@gmail.com
}

\begin{abstract}
ABSTRAK
Permukiman RT.06 RW.05 Kelurahan Penanggungan merupakan permukiman dengan kondisi lahan berkontur yang berada di bantaran Sungai Brantas. Permukiman ini memiliki kepadatan penduduk yang cukup tinggi sehingga memiliki lahan terbuka yang terbatas. Ada sebagian lahan terbuka yang dimiliki warga RT.06 RW.05 yang dimanfaakan sebagai tempat berkumpul dan bersosialisasi. Hal tersebut antara lain diwujudkan melalui pemanfaatan lahan terbuka untuk mushola dan ruang bersama sebagai pusat sosial dan keagamaan. Dalam rancangan tata ruang mushola ini diharapkan keberadaannya sangat berpengaruh terhadap kenyamanan dan keselarasan terhadap lingkungannya. Penelitian ini menggunakan metode deskriptif kualitatif dengan pendekatan eko-desain. Potensi tapak yang sudah ada sangat mendukung konsep rancangan eko-desain atau eko-arsitektur (desain yang berbasis alam). Hasil penelitian ini menunjukkan bahwa peran desain tata ruang mushola ini memberikan suasana lingkungan alam tetap terjaga dengan baik dan juga tidak merugikan lingkunganya. Untuk itu perlu dijaga keseimbangan antara lingkungan alam, manusia dan teknologi.
\end{abstract}

Kata kunci: tata ruang mushola, ruang terbuka, lahan berkontur, fungsi ekodesain

\begin{abstract}
RT.06 RW.05 Settlement of Penanggungan Village is a community with contoured land located on the banks of the Brantas river. Due to the settlement's relatively high population density, it has a limited amount of open space. Residents of RT.06 RW.05 own some open spaces that they utilize for gatherings and socializing. Among other things, this situation is fulfilled through the utilization of open land for prayer rooms and communal spaces as social and religious centers. It is envisaged that the musalla's spatial design would have a significant impact on the comfort and harmony of the surrounding environments. This research employed a qualitative
\end{abstract}


descriptive technique in conjunction with an eco-design approach. The existing site potential lends considerable support to the eco-design or ecoarchitecture concepts (nature-based design). According to the findings of this research, the musalla 's spatial design's purpose is to create an ambiance of the natural environment that is both well-maintained and does not affect the environment. As a result, a balance must be maintained between the natural environment, people, and technology.

\section{Keywords: musalla layout, open space, contoured land, eco-design function}

\section{PENDAHULUAN}

RT.06 RW.05 merupakan permukiman perkotaan yang berada di daerah kelurahan Penanggungan, Kecamatan Klojen, Kota Malang. Potensipotensi tapak yang dimiliki permukiman ini antara lain adalah banyaknya sumber mata air sehingga di sebut kampung bening, memiliki lahan berkontur, karena posisi berada di bantaran sungai Brantas (berdekatan dengan jembatan gantung menuju ke wilayah kecamatan Blimbing) serta memiliki lahan terbuka yang masih bisa di manfaatkan oleh warga.

Permukiman Perkotaan memiliki lahan terbatas karena kepadatan penduduk membuat ruang yang semakin meningkat. Hal ini dapat dilihat di wilayah permukiman RT. 06 RW. 05 Penanggungan, Kecamatan Klojen, Kota Malang. Warga permukiman ini memanfaatkan sebagian dari lahan terbuka yang sempit ini untuk tempat berkumpul dan bersosialisasi. Pemanfaatan ruang terbuka tersebut dijadikan pusat sosial keagamaan, berupa mushola dan ruang bersama.

Dalam rancangan tata ruang mushola ini diharapkan dapat menyatu dengan alam, sehingga kualitas lingkungannya menjadi meningkat dan juga dapat melindungi kesehatan masyarakatnya. Terutama dalam pemenuhan fungsi eko-desain, sehingga potensi tapak yang tersedia dapat bermanfaat untuk keutuhan ekologi kota serta kesehatan warga. Untuk itu keselarasan antara manusia dan lingkungan alamnya akan terjaga dengan baik.

\section{TINJAUAN PUSTAKA}

Menurut Hakim, R. (2018), ruang terbuka dilihat dari kegiatannya terdiri dari dua (2) macam yaitu; ruang terbuka aktif dan pasif. Ruang terbuka aktif memiliki unsur-unsur kegiatan di dalamnya, seperti bermain, olahraga, atau jalan-jalan. Contoh ruang terbuka aktif, yaitu plaza, lapangan olahraga, penghijauan tepi sungai sebagai sarana rekreasi masyarakat, dan area bermain anak.

Peraturan Menteri Pekerjaan Umum, No. 05/PRT/M/2008 Tentang Pedoman Penyediaan Dan Pemanfaatan Ruang Terbuka Hijau Di Kawasan 
Perkotaan, Bahwa Ruang Terbuka Terdiri; Ruang Terbuka Hijau Dan Ruang Terbuka Non Hijau, Ruang Terbuka Hijau (RTH) merupakan area memanjang dan mengelompok, yang penggunaannya bersifat terbuka, tempat tumbuh tanaman baik bersifat alamiah maupun sengaja ditanam, Ruang Terbuka Non Hijau merupakan ruang yang tidak termasuk dalam kategori RTH, berupa lahan perkerasan maupun yang berupa badan air.

Ruang Terbuka Hijau (RTH) memiliki fungsi sebagai berikut : Fungsi Ekologis (sebagai pengatur iklim mikro, menjadi paru-paru kota, mengurangi polusi, menyerap air hujan dan penyedia habitat satwa); Fungsi Sosial Dan Budaya (menggambarkan ekspresi budaya lokal; media berkumpul dan media berkomunikasi warga, rekreasi dan sebagai tempat pendidikan, penelitian, dan pelatihan); Fungsi Ekonomi (sebagai peningkatan ekonomi dengan menjual produk (tanaman, bunga sayur dan buah), dan juga menjadi usaha dalam bidang pertanian perkebunan dan kehutanan); Fungsi Estetika (meningkatkan kenyamanandan keindahan kota, menciptakan Suasana keserasian dan kesinambungan antara area terbangun dan tidak terbangun)

Syahadat, dkk (2017) menyatakan bahwa dalam meningkatkan kualitas kesehatan publik dengan luasan lahan yang terbatas yaitu dengan pemanfaatan vegetasi yang efektif untuk mengurangi pencemar udara; pemanfaatan pekarangan rumah; penerapan penghijauan vertikal; pemanfaatan dalam ruangan kebun; dan juga menjaga keberadaan taman kota.

Dalam Proses berarsitektur, pendekatan desain yang ekologis (desain berbasis alam) dapat menciptakan suatu arsitektur yang ekologis (EkoArsitektur). Desain yang dalam perancangannya menggunakan alam, menggabungkan alam dan teknologi, strategi konservasi, perbaikan lingkungan serta semua tingkat dan skala bangunan, lansekap, permukiman dan perkotaan (Sukawi, 2008).

Pemikiran siklus hidup (LCT-Life Cycle Thinking) yang diterapkan dalam eko desain memberikan perspektif yang komprehensif, yaitu mempertimbangkan dampak lingkungan dari proses desain, fabrikasi yang dikontrol sendiri, memperhatikan penggunaan bahan, rantai pasokan, penggunaan produk, efek pembuangan dan kemungkinan penggunaan kembali serta mendaur ulang (Ustvarjalnosti, I. 2013). Sedangkan penerapan pendekatan eko-desain dalam pengembangan produk konstruksi yang berkelanjutan sangat diinginkan karena dapat berkonstribusi terhadap keberlanjutan, efisiensi energi, daya saing ekonomi, persediaan membangun dan kota yang ramah lingkungan. (Marques, et al. 2017). Studi tentang Penilaian Siklus Hidup (LCA-Life Cycle Assessment) yang telah diterapkan pada bangunan hemat energi, menunjukkan bahwa perilaku pengguna sangat berpengaruh terhadap kinerja bangunan dan lingkungan (Peuportie, B., et al. 2013).

PAWON: Jurnal Arsitektur, Nomor 01 Volume VI, Januari-Juni Tahun 2022, ISSN 2597-7636 
Heinz Frick (1998) menjabarkan bahwa eko-arsitektur mencakup keselarasan antara manusia dan lingkungan alamnya, serta mengandung juga dimensi lain seperti waktu, lingkungan alam, sosio-kultur, ruang serta teknik bangunan. Sedangkan prinsip-prinsip bangunan ekologis yang dimilki Heinz Frick antara lain; penyesuaian terhadap lingkungan alam setempat; Menghemat sumber energi alam yang tidak dapat diperbaharui dan menghemat penggunaan energi; Memelihara sumber lingkungan, Memelihara dan memperbaiki peredaraan alam; Mengurangi ketergantungan kepada sistem pusat energi (listrik, air) dan limbah (air limbah dan sampah); Penghuni ikut serta secara aktif pada perencanaan pembangunan dan pemeliharaan perumahan; Tempat Kerja dan permukiman dekat; Penghuni menghasilkan sendiri kebutuhannya sehari-hari dan Menggunakan teknologi sederhana.

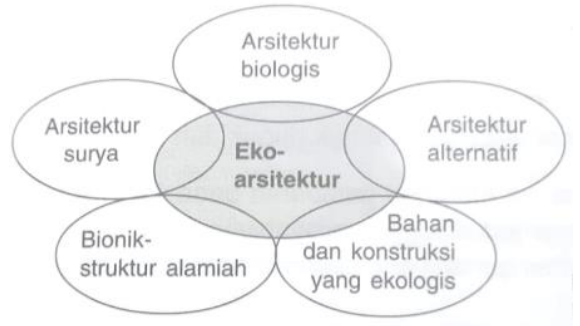

Gambar. 1

Konsep eko-arsitektur yang holistic (sistem keseluruhan)

Sumber: Frick, 1998

Konsep eko-arsitektur mencakup semua bidang, bidang arsitektur biologis, arsitektur alternatif, bahan dan konstruksi yang ekologis, bionikstruktur yang alamiah dan arsitektur surya.

Berdasarkan penelitian sebelumnya Winarni.S, Pramitasari.P, $\mathrm{H}$, Istiqoma, M. 2021 didapatkan hasil bahwa konsep desain mushala ini dioptimalkan pada pemanfaatan lahan terbatas melalui efisiensi fungsi dan ruang serta optimasi green space pada lahan berkontur curam berupa vertical garden pada kondisi lahan berkontur curam sehingga lahan eksisting dapat berfungsi optimal sebagai lahan aktif dan kontekstual dengan lingkungan sekitarnya, Konsep tersebut menjadi dasar untuk pengembangan desain pra rancangan mushola yang berbasis alam, selaras antara manusia dan lingkungan alamnya.

\section{METODE PENELITIAN}

Penelitian ini mengkaji pemenuhan fungsi eco desain pada desain tata ruang mushola yang berada pada lahan berkontur dan sempit. Metode penelitian yang digunakan adalah metode penelitian deskriptif kualitatif dengan pendekatan fungsi eko-desain (eko-arsitektur). Metode pengumpulan data ada dua; data primer melalui observasi dan wawancara, data sekunder 
melalui dokumen dan informasi buku, publikasi penelitian sejenis. Analisis yang dilakukan dengan mengkaji peran desain tata ruang mushala Al-Hidayah RT.06 RW.05 Kelurahan Penanggungan, Kota Malang terhadap pemenuhan fungsi eko-desain. Desain tata ruang mushola akan di kaji dengan 8 (delapan) prinsip-prinsip bangunan ekologis (frick, 1998); Penyesuaian terhadap lingkungan setempat, menghemat penggunaan energi, memelihara lingkungan alam, mengurangi ketrgantungan pada sistem pusat energi, penghuni aktif dalam perencanaan dan pemeliharaan perumahan, tempat kerja dan permukiman terdekat, penghuni menghasilkan sendiri kebutuhan sehari-hari dan penggunaan teknologi sederhana.

\section{HASIL DAN PEMBAHASAN}

Pembahasan hasil penelitian ini dilakukan untuk mengetahui peran desain tata ruang mushola terhadap pemenuhan fungsi eko-desain, yang dikaji melalui prinsip - prinsip bangunan ekologis (eko-arsitektur) :

\section{a) Penyesuaian terhadap lingkungan alam setempat}

Rancangan dalam tata ruang mushola ini mengikuti atau menyesuaikan pada lingkungan setempat yaitu dengan penggunaan tumbuhan dan air sebagai pengatur iklim, sehingga menciptakan dampak positif terhadap lingkungannya. Berikut adalah penerapan prinsip terhadap lingkungan alam setempat adalah dengan memanfaatkan sumber mata air yang ada dengan menambahkan tandon sebagi tempat berwudhu dan menyiram tanaman, kemudian yang kedua memanfaatkan lahan berkontur dengan vertical garden.
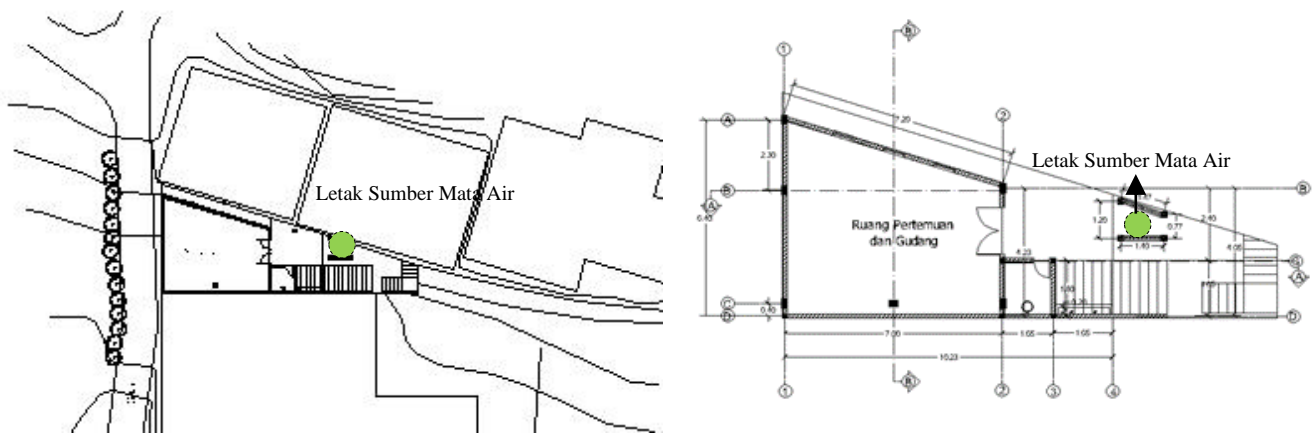

Gambar. 1

Letak letak posisi sumber mata air ditapak

Sumber: analisis penulis, 2021 

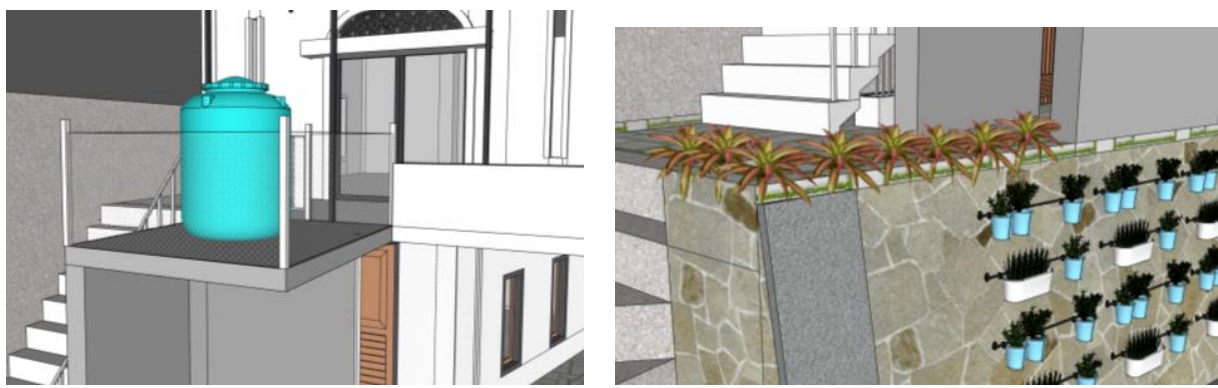

Gambar. 2

Letak tandon air dan penempatan tanaman vertikal garden di retaining wall Sumber: analisis penulis, 2021

\section{b) Menghemat penggunaan energi.}

Meminimalisasi penggunaan energi listrik dengan memperbanyak bukaan-bukaan pada bangunan serta menggurangi penggunaan daya pompa air, dengan menggunakan proses penyiraman vertikal garden dengan proses hidroponik dan vertikultur. Pengembangan selanjutnya dimungkinkan untuk merencanakan tenaga listrik panel surya dan kincir air untuk menerangi ruangan di malam hari, khususnya di tempat ibadah.
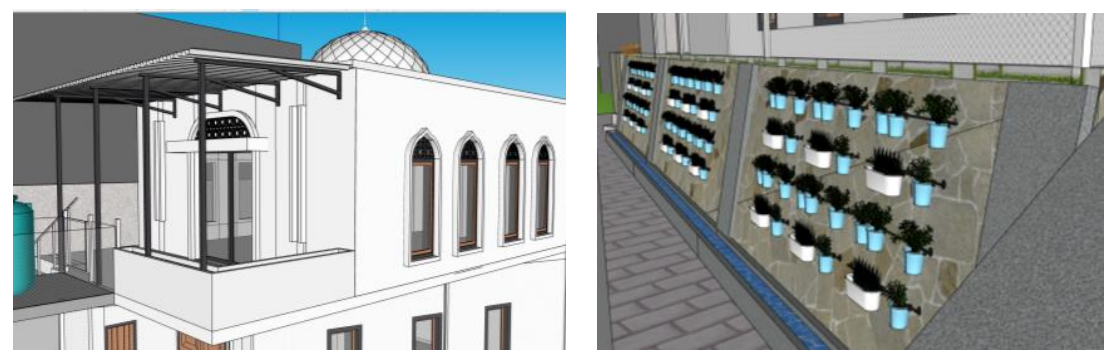

Gambar. 3

Bukaan-bukaan jendela dan tanaman vertikal garden Sumber: analisis penulis 2021

\section{c) Memelihara sumber lingkungan, Memelihara dan memperbaiki peredaraan alam,}

Menjaga sumber lingkungan yang ada dengan menghemat sumber alam, penerapannya adalah sebagai berikut : penyediaan sumber air bersih untuk lingkungan sekitar mushola, membuat saluran air limbah dan air hujan di lingkungan mushola. Konsep ruang pada rancangan musala ini diarahkan ke suasana alami, hal ini didukung dengan wilayah RT.06 ini dijuluki sebagai kampung bening, serta posisinya berada di lahan berkontur dekat dengan bantaran sungai Brantas, sehingga penyatuaan konsep ruang dalam dan ruang luarnya disesuaikan dengan kontekstual dengan lingkungan sekitar. 


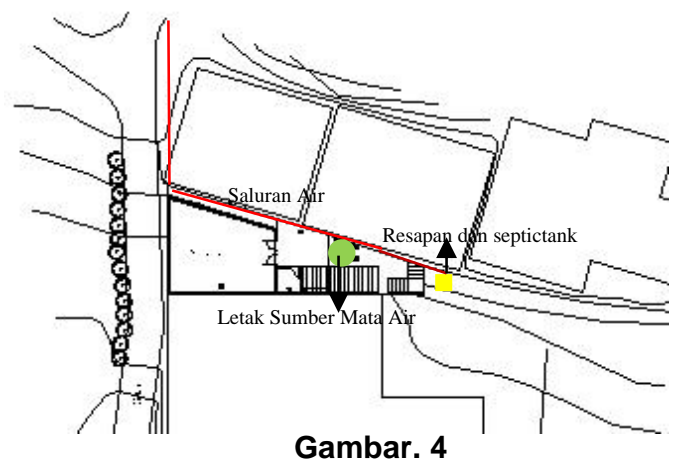

Letak sumber air, septictank dan resapan air Sumber: analisis penulis 2021

\section{d) Mengurangi ketergantungan kepada sistem pusat energi (listrik, air)} dan limbah (air limbah dan sampah)

Pengurangan penggunaan energi listrik yaitu dengan pembuatan tandon sehingga penggunaan daya pompa tidak terlalu banyak, apalagi frekuansi penggunaan mushola tidak sebanyak dengan kebutuhan rumah tangga. Pembuangan air limbah pun juga tidak banyak mengandung zat atau lemak yang banyak di karenakan penggunaan air hanya untuk berwudhu dan cuci karpet, penerapannya dengan dibuatkan resapan air di lingkungan tapak.

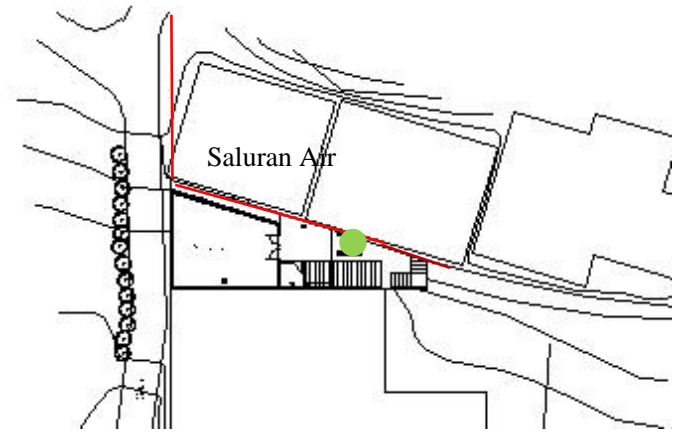

Gambar. 5

Saluran air hujan menuju sungai

Sumber: analisis penulis 2021

\section{e) Penghuni ikut serta secara aktif pada perencanaan pembangunan dan pemeliharaan perumahan}

Masyarakat dilingkungan permukiman RT.06 RW.05 keluarahan penanggungan ini rukun guyup dalam berpartisipasi pembangunan mushola, karena fasilitas mushola ini sangat diharapkan segera terbangun, dan bisa di manfaatkan. 


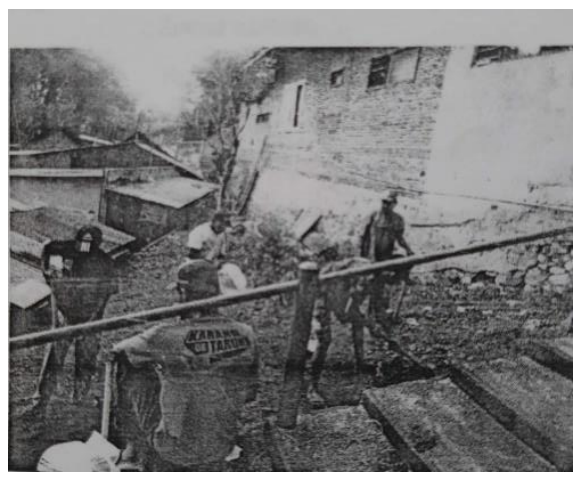

Gambar. 6

Kegiatan Warga meratakan lahan

Sumber: dokumentasi warga RT.06 RW.05

\section{f) Tempat Kerja dan permukiman dekat}

Permukiman ini lokasinya di dataran rendah dari kemiringan Jl. Mayjen Panjaitan. Lokasi tapak berada di jalan yang merupakan jalan pintas menuju jembatan ke arah kecamatan Lowokwaru. Untuk itu jalan tersebut menjadi jalan padat kendaraan bermotor dalam setiap harinya, penerapan dalam desain untuk menguranginya kebisingan dan gas buangan motor maka sisi sebelah barat di desain dengan menambahakan tanaman untuk menguranginya.

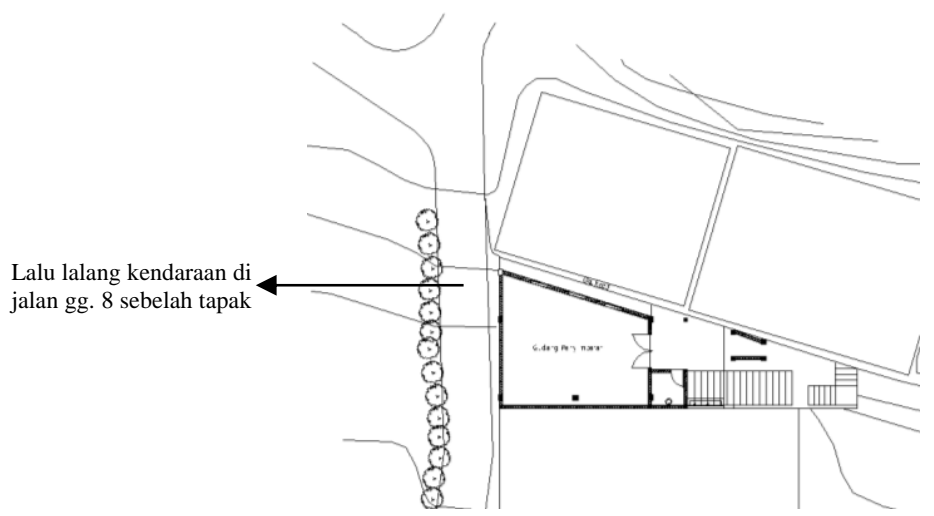

Gambar. 2

Jalan sebelah tapak mushola

Sumber: Analisis penulis 2021

\section{g) Kemungkinan penghuni menghasilkan sendiri kebutuhannya sehari-hari.}

Dengan Memanfaatkan tanaman hidroponik dan vertikultur maka masyarakat sekitar mushola dapat menghasilkan kebutuhan sendiri yang lebih sehat dan serta dapat melestarikan lingkungan yang sangat padat. 


\section{h) Menggunakan teknologi sederhana.}

Teknologi yang ekologis mengutamakan keseimbangan antara teknologi dan lingkungan; seimbang dengan alam dengan memperhatikan alam dan sumbernya, seimbang dengan manusia dengan memperhatikan keamanan, kehidupan (air, jalan dan penghidupan), kebudayaan, sumber alam, pencemaran udara, kesehatan, pendidikan,dan sebagainya; seimbang dengan lingkungan dengan memperhatikan pengaruh dari iklim, tanah, dan pengaruh lainnya.

Penerapannya adalah dengan memanfaatkan sumber mata air yang ada untuk kebutuhan muhola dan warga setempat, memanfaatkan tanah/lahan berkontur yang ada dengan teknologi yang sederhana sesuai dengan prinsip teknologi yang ekologis yaitu dengan menambahkan tanaman vertikal garden, atau menambahkan tanaman gantung pada desain muhola.

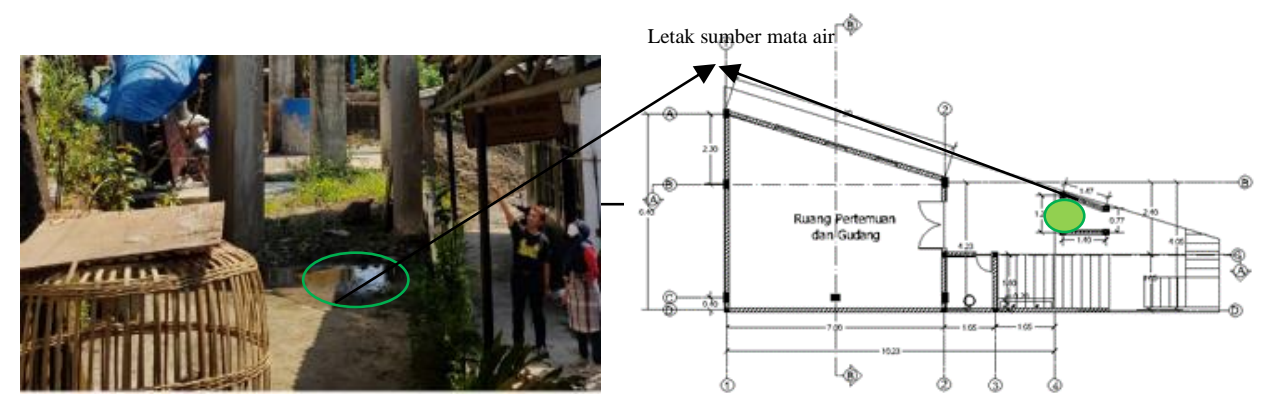

Gambar. 2

Letak sumber mata air

5. KESIMPULAN

Sumber: dokumentasi penulis,2021

Hasil dari penelitian ini bahwa desain tata ruang mushola hanya memiliki 7 (tujuh) prinsip bangunan ekologis (Frick 1998) yang terpenuhi, ada satu yang belum terpenuhi yaitu energi terbarukan, namun jika diamati dari potensi yang ada bahwa permukiman ini memiliki potensi energi yang cukup baik untuk dikembangkan, contoh pengembangan energi listrik dengan menggunakan panel surya atau energi listrik menggunakan arus sungai Brantas yang ada di sekitar tapak.

Potensi tapak yang sudah ada sangat mendukung konsep rancangan eko-desain atau eko-arsitektur (desain yang berbasis alam). Peran desain tata ruang mushola ini memberikan suasana lingkungan alam tetap terjaga dengan baik dan tidak merugikan lingkunganya. Maka dari itu yang harus kita utamakan adalah menjaga keseimbangan antara lingkungan alam, manusia dan teknologi.

Penelitian selanjutnya adalah mengembangkan desain pra rancangan ke dalam rancangan untuk di wujudkan ke dalam tata ruang yang bermanfaat untuk masyarakat warga RT.06 RW.05 Kelurahan Penanggungan.

PAWON: Jurnal Arsitektur, Nomor 01 Volume VI, Januari-Juni Tahun 2022, ISSN 2597-7636 


\section{DAFTAR PUSTAKA}

Frick, H.(1998). Dasar Dasar Arsitektur Ekologis. Kanisius: Yogyakarta.

Frick, H.(2006). Arsitektur Ekologis Kanisius: Yogyakarta.

Hakim, R. (2018). Komponen Perancangan Arsitektur Lansekap; Prinsip Unsur dan Aplikasi Desain. Jakarta: PT. Bumi Aksara.

Kementerian Pekerjaan Umum, 2008, Permen PU No. 05/PRT/M/2008 tentang Pedoman Penyediaan dan Pemanfaatan Ruang Terbuka Hijau di Kawasan Perkotaan, Jakarta: Direktorat Jenderal Tata Ruang.

Marques, B., Tadeu, A., De Brito, J., Almaedi, J. (2017). A Perspective on the development of Sustainable Construction Products: An Eco-Design Approach. The $6^{\text {th }}$ International Conference on Harmonisation between Architecture and Nature (Eco-Architecture2016), 12(2), 304-314.

Peuportier, B., Thiers, S.,Guiavarch, A. (2013). Eco-Design of Building Using Thermal Simulation and Life Cycle Assessment. Journal of Cleaner Production. 39, 73-78.

Sukawi.(2008), Ekologi Arsitektur: Menuju Perancangan Arsitektur Hemat Energi dan Berkelanjutan. Simposium Nasional RAPI VII.

Syahadat, R.M., Putra, P.T., Pratiwi, M.D. (2017). Ruang Terbuka Hijau Dan Permasalahan Kesehatan Perkotaan, Studi Kasus Di Provinsi DKI Jakarta. E-Jurnal Arsitektur Lansekap, 3(2), 179-188.

Ustvarjalnosti, I.(2013). Minimum Game Plans, Eco-design and Low-Tech Fabrication in Studios. The Creativity Game-Theory and Practice of Spatial Planning. (1)1, 30-35.

Winarni, S., Pramitasari, H.P., Istiqoma, M. (2021). Optimizing The Use of Active Open Space of Al Hidayah Musala Design Concept at RT 06 RW 05 Penanggungan Village, Lowokwaru Sub District, Malang. ESE International Journal. 4(1), 15-20. 